\title{
40. DATA REPORT: OCCURRENCE OF DOLOMITE AT SITE 768 (SULU SEA) ${ }^{1}$
}

\author{
Christian Betzler ${ }^{2}$
}

\section{INTRODUCTION}

Occurrence of deep-sea dolomites has been reported from numerous settings (for discussion see Lumsden, 1988). Different authors agree that dolomite formation in the pelagic realm is a relatively early diagenetic process (e.g., Jorgensen, 1983; Shimmield and Price, 1984; Kablanow et al., 1984; Kulm et al., 1984). Baker and Burns (1985) suggest that most of the pelagic dolomites formed within a few tens of meters below the seafloor within the zone of microbial sulfate reduction. According to Füchtbauer and Richter (1988), dolomite can form in the deep-sea at a minimum temperature of $10^{\circ} \mathrm{C}$. Other deep-sea dolomites are products of fluids derived from underlying evaporites or submarine weathering of basalts (Garrison, 1981). In some cases (Mullins et al., 1985; Dix and Mullins, 1988; Mullins et al., 1988), the existence of dolomite is linked to disconformities and its formation may have resulted from circulation of seawater through the sediment during prolonged exposure (Dix and Mullins, 1988, p. 287).

At Site 768 (Fig. 1), lithified carbonate layers, some containing variable amounts of dolomite, occur below $201 \mathrm{mbsf}$ (Miocene). These beds alternate with unconsolidated or semi-lithified marl layers interbedded in clays and siliciclastic turbidites. The irregular depth distribution of the limestone beds and the variation in preservation and recrystallization of the calcareous microfaunas suggest that lithification of carbonates at Site 768 not only reflects burial diagenesis as described by Garrison (1981) and others, but in part may be a selective, early diagenetic process. The different types and distribution of the dolomite additionally seem to support this assumption.

The purpose of this report is to document the occurrence and textural nature of the dolomite at Site 768. Methods used were analyses of stained thin sections (Alizarin S and Ferrocyanide) and studies with the scanning electron microscope. No geochemical analyses (e.g., stable isotopes) were carried out; they will be the subject of further investigations.

\section{CARBONATE LITHOFACIES AND SAMPLE DESCRIPTION}

Two main carbonate lithofacies occur at Site 768 :

1. Within the upper part of the succession (late Pliocene to Pleistocene) thin- to thick-bedded pelagic nannofossil-foraminifer oozes and marls with sponge spicules, silicoflagellates, and radiolarians. These deposits indicate deposition near or at the carbonate compensation depth.

2. Redeposited bioclastic carbonates occurring as carbonate turbidites of pelagic origin throughout the whole section (middle Miocene to Pleistocene). The microfaunas of these layers are dominated by planktonic foraminifers with minor amounts of benthic foraminifers.

\footnotetext{
'Silver, E. A., Rangin, C., von Breymann, M. T., et al., 1991. Proc. ODP, Sci. Results, 124: College Station, TX (Ocean Drilling Program),

${ }^{2}$ Geologisch-Palăontologisches Institut, Senckenberganlage 32-34, D-6000 Frankfurt am Main 11, Federal Republic of Germany.
}

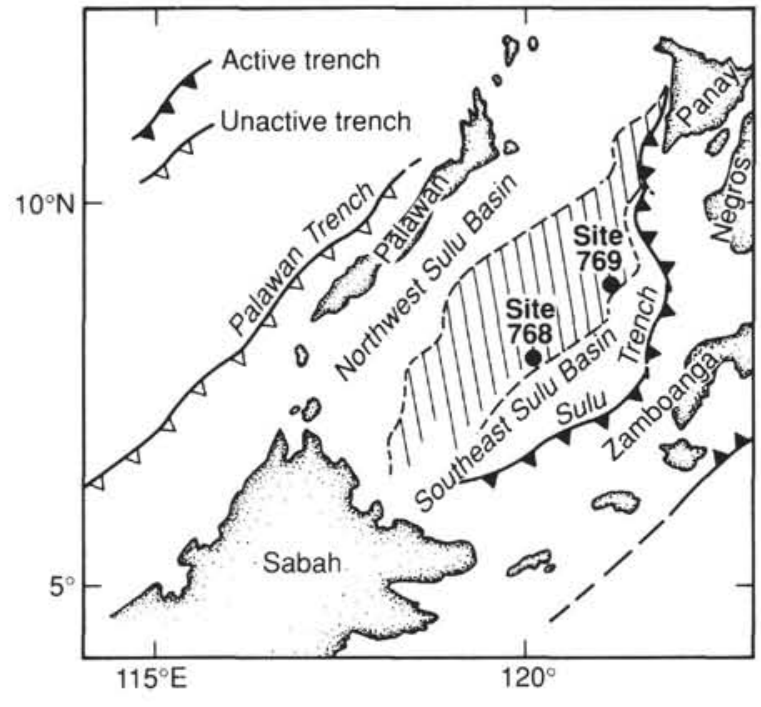

Figure 1. Location map of Site 768.

The analyzed samples were taken from the lithified calcareous layers occurring below $201 \mathrm{mbsf}$ at Site 768 (Table 1), which are 5 to $15 \mathrm{~cm}$ thick and are interpreted as pelagic turbidites. The layers are bioturbated, in some cases burrows are preserved as voids, others are infilled with pellets (Pl. 1, Fig. 1). Some beds show a weak normal grading.

Sedimentation rates are $52 \mathrm{~cm} / \mathrm{m}$.y. between 203.35 and 358.1 mbsf, $48 \mathrm{~cm} / \mathrm{m}$.y. between 358.1 and $392.13 \mathrm{mbsf}$, and 293 $\mathrm{cm} / \mathrm{m}$.y. between 392.13 and $714.20 \mathrm{mbsf}$ (Fig. 2; Rangin, Silver, von Breymann, et al., 1990).

\section{THIN-SECTION AND SEM ANALYSIS}

In the studied samples dolomite occurs as:

1. Pore filling (D1): In unfilled burrows dolomite rhomboeders $5-20 \mu \mathrm{m}$ in size have grown on the pore walls (Pl. 1, Figs. 2, 3). Crystal size within the pores augments centripetally. The crystals tend to be limpid and are intergrown. Crystal surfaces are smooth to slightly irregular. The boundary of the dolomite and the surrounding micrite and microspar is not well defined.

2. Anhedral to subhedral dolomite (D2): This type of finegrained dolomite occurs in cloudy patches with a sugary texture dispersed within the micrite or microspar (PI. 1, Fig. 5). It may be partly linked to small voids and coarser grained patches that are relict structures of recrystallized foraminifers. The voids can lead to a considerable porosity of the rock.

3. Disseminated dolomite rhomboeders in the micrite and microspar (D3): In various samples (Table 1) dolomite rhomboeders, 20 to $30 \mu \mathrm{m}$ in size, are disseminated throughout the sediment (Pl. 1, Fig. 4). The rhomboeders are limpid and well developed with smooth to somewhat irregular crystal surfaces. In some 
Table 1. Occurrence and type of dolomite (see text for further explanation) in the analyzed samples from Site $\mathbf{7 6 8 .}$

\begin{tabular}{|c|c|c|c|c|}
\hline $\begin{array}{l}\text { Core, section, } \\
\text { interval }(\mathrm{cm})\end{array}$ & $\begin{array}{l}\text { Pore fill } \\
\text { (D1) }\end{array}$ & $\begin{array}{l}\text { Clouds } \\
\text { diss. } \\
\text { (D2) }\end{array}$ & $\begin{array}{l}\text { Rhomboeders } \\
\text { (D3) }\end{array}$ & $\begin{array}{c}\text { Foss. } \\
\text { preserv.* }\end{array}$ \\
\hline \multicolumn{5}{|l|}{$124-768 \mathrm{~B}-$} \\
\hline $23 \mathrm{H}-1,2-6$ & + & & & ++ \\
\hline $25 \mathrm{X}-\mathrm{CC}, 3-5$ & + & + & & - \\
\hline $25 \mathrm{X}-\mathrm{CC}, 49-51$ & & + & + & +- \\
\hline $36 \mathrm{X}-\mathrm{CC}, 31-33$ & & & + & + \\
\hline \multicolumn{5}{|l|}{$124-768 \mathrm{C}$. } \\
\hline $1 \mathrm{R}-1,0-4$ & & & + & + \\
\hline $1 \mathrm{R}-1,59-63$ & & & + & + \\
\hline $2 \mathrm{R}-1,29-32$ & + & + & & - \\
\hline 3R-CC, 11-13 & & & & - \\
\hline $9 \mathrm{R}-2,126-128$ & & & + & - \\
\hline $30 \mathrm{R}-1,141-143$ & & & + & + \\
\hline $33 R-6,27-29$ & & & & ++ \\
\hline $35 \mathrm{R}-1,23-25$ & & & & \\
\hline
\end{tabular}

cases, smaller carbonate particles are incorporated in the dolomite crystals.

Dolomite abundance was estimated visually. It is most abundant in Samples 124-768B-23H-1, 2-6 cm, 768B-25X, CC, 3-5 $\mathrm{cm}$, and $49-51 \mathrm{~cm}$, followed by the samples $124-768 \mathrm{C}-2 \mathrm{R}-1$, 29-32 cm, and $768 \mathrm{C}-1 \mathrm{R}-1,0-4 \mathrm{~cm}$. The other samples contain very small amounts of dolomite or none at all.

\section{OTHER ASPECTS OF DIAGENESIS}

The recrystallization and the state of preservation of the calcareous microfossils is not only related to depth but is subject to strong changes within the sedimentary sequence at Site 768 (Table 1). Below the poorly preserved, recrystallized faunas of Samples 124-768B-23H-1, 2-26 cm (2401.2 mbsf) to 124-768C9R-2, 126-128 cm (432.96 mbsf), samples with very well-preserved microfaunas occur (e.g., 124-768C-33R-6, 27-29 cm, $669.87 \mathrm{mbsf}$ ). This and the irregular distribution of dolomite points to a differentiated diagenesis of the carbonates at Site 768.

\section{DISCONFORMITIES AND REPARTITION OF LITHIFIED CARBONATES}

Figure 2 shows the depth distribution of the lithified carbonate beds (see also Table 1) and the occurrence of the various types of dolomite. Two intervals with closely spaced lithified beds underlie two disconformities. Few other indurated beds occur within the remaining succession interbedded in clays and siliciclastic turbidites.

The disconformities are defined by the evolution of the turbidite systems and by biostratigraphic data (Betzler et al., this volume). The latest Miocene disconformity may correspond to the limit of a depositional sequence which is characterized by a slight increase of the siliciclastic input within the overlying sediments. The lower, late Miocene disconformity corresponds to a condensed section (NNIO).

\section{RESULTS}

At Site 768 three types of dolomite are differentiated:

1. Pore-filling dolomite in voids related to bioturbation (Dl).

\section{SITE 768}
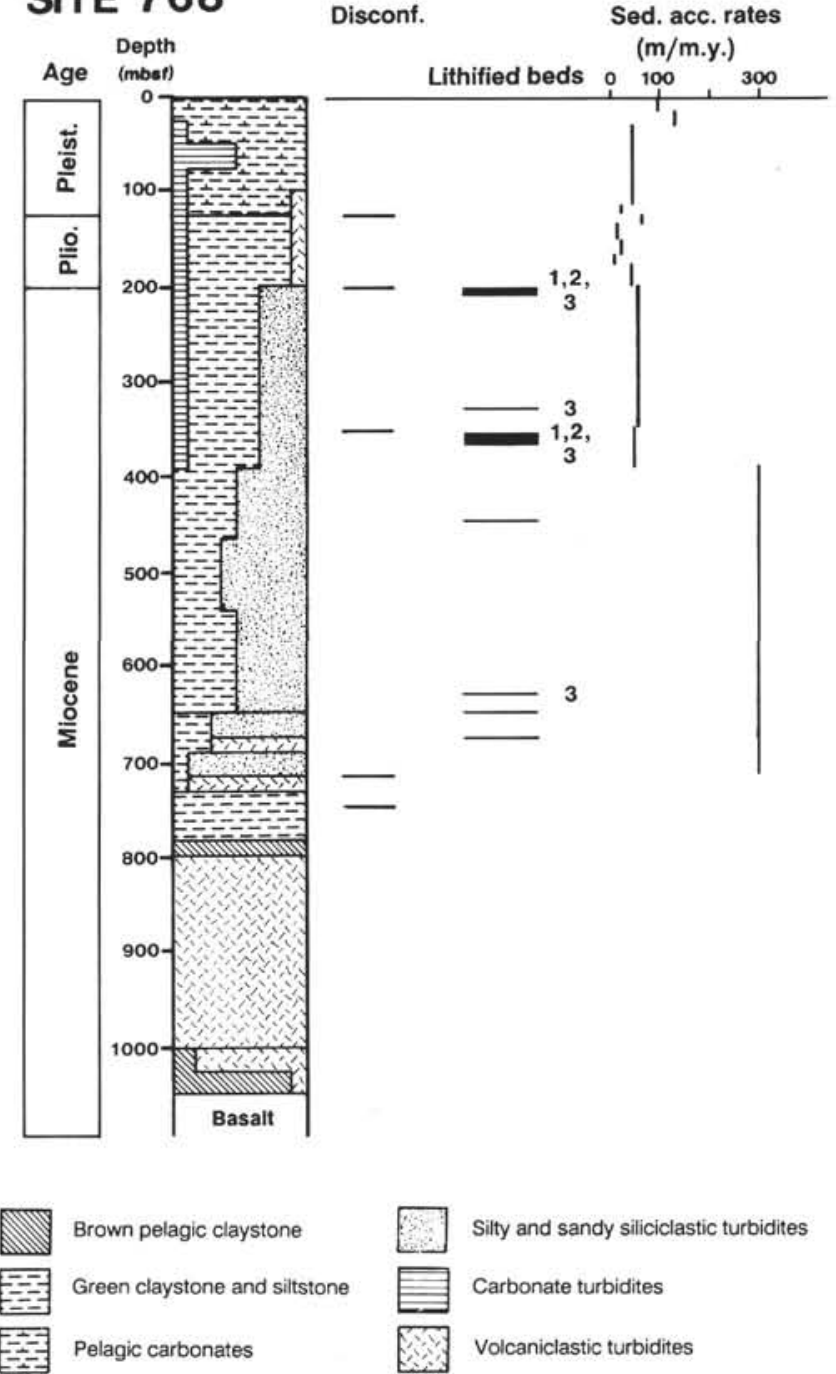

Figure 2. Sedimentary succession at Site 768 with sedimentary disconformities (turbidite systems), positions of lithified carbonates, and sediment accumulation rates. Items 1, 2, 3 refer to the different dolomite types (see text for further explanation).

2. Dolomite arranged in cloudy patches that are partially related to recrystallized foraminifers (D2).

3. Large, disseminated dolomite rhomboeders (D3). Two intervals with closely spaced, lithified carbonate layers containing type 1 and 2 dolomite occur below sedimentary disconformities.

The dolomite content and crystal size of the dolomite at Site 768 do not increase with depth.

\section{REFERENCES}

Baker, P. A., and Burns, S. J., 1985. Occurrence and formation of dolomite in organic-rich continental margin sediments. AAPG Bull., 69:1917-1930.

Dix, G. R., and Mullins, H. T., 1988. A regional perspective of shallowburial diagenesis of deep-water periplatform carbonates from the Northern Bahamas. In Austin, J. A., Jr., Schlager, W., et al., Proc. ODP, Sci. Results, 101: College Station, TX (Ocean Drilling Program), 279-302.

Füchtbauer, H., and Richter, D. K., 1988. Karbonatgesteine. In Füchtbauer, H. (Ed.), Sedimente und Sedimentgesteine (4th ed.): Stuttgart (Schweizerbart), 233-434. 
Garrison, R. E., 1981. Diagenesis of oceanic carbonate sediments: a review of the DSDP perspective. Soc. Econ. Paleontol. Mineral., Spec. Publ., 32:181-207.

Jorgensen, N. O., 1983. Dolomitization in chalk from the North Sea Central Graben. J. Sediment. Petrol., 53:557-564.

Kablanow, R. I., Surdam, R. C., and Prezbindowski, D., 1984, Origin of dolomites in the Monterey Formation: Pismo and Huasna basins, California. In Surdam, R. C. (Ed.), Stratigraphic, Tectonic, Thermal, and Diagenetic Histories of the Monterey Formation, Pismo and Huasna Basin, California. Soc. Econ. Paleontol. Mineral Guidebook, 2:38-49.

Kulm, L. D., Suess, E., and Thornburg, T. M., 1984. Dolomites in the organic-rich muds of the Peru forearc basins: analogue to the Monterey Formation. In Garrison, R. E., Kastner, M., and Zenger, D. H. (Eds.), Dolomites in the Monterey Formation and Other Organic-rich Units: Soc. Econ. Paleontol. Min. Spec. Publ., 41:29-48.

Lumsden, D. N., 1988. Characteristics of deep-marine dolomite. I. Sediment. Petrol., 58:1023-1031.
Mullins, H. T., Dix, G. R., Gardulski, A. F., and Land, L. S., 1988. Neogene deep-water dolomite from the Florida-Bahamas Platform. Soc, Econ. Paleontol. Mineral. Spec. Publ., 43:235-243.

Mullins, H. T., Wise, S. W., Jr., Land, L. S., Siegel, D. I., Masters, P. M., Hinchey, E. J., and Price, K. R., 1985. Authigenic dolomite in Bahamian periplatform slope sediment. Geology, 13:292-295.

Rangin, C., Silver, E. A., von Breymann, M. T., et al., 1990. Proc. ODP, Init. Repts., 124: College Station, TX (Ocean Drilling Program).

Shimmield, G. B., and Price, N. B., 1984. Recent dolomite formation in hemipelagic sediments off Baja California, Mexico. In Garrison, R. E., Kastner, M., and Zenger, D. H. (Eds.), Dolomites of the Monterey Formation and Other Organic-Rich Units: Pacific Section Soc. Econ. Paleontol. Mineral., 41:5-18.

Date of initial receipt: 14 May 1990

Date of acceptance: 27 November 1990

Ms 124B-141 


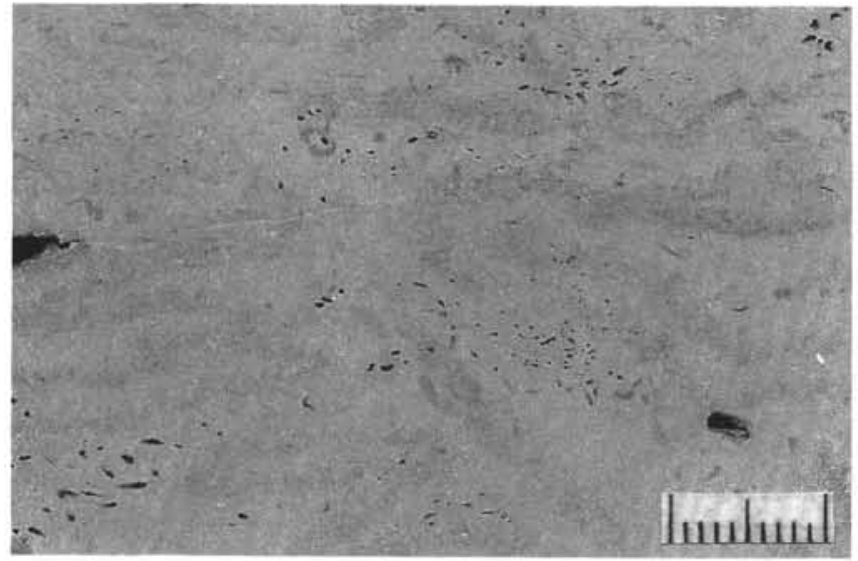

1

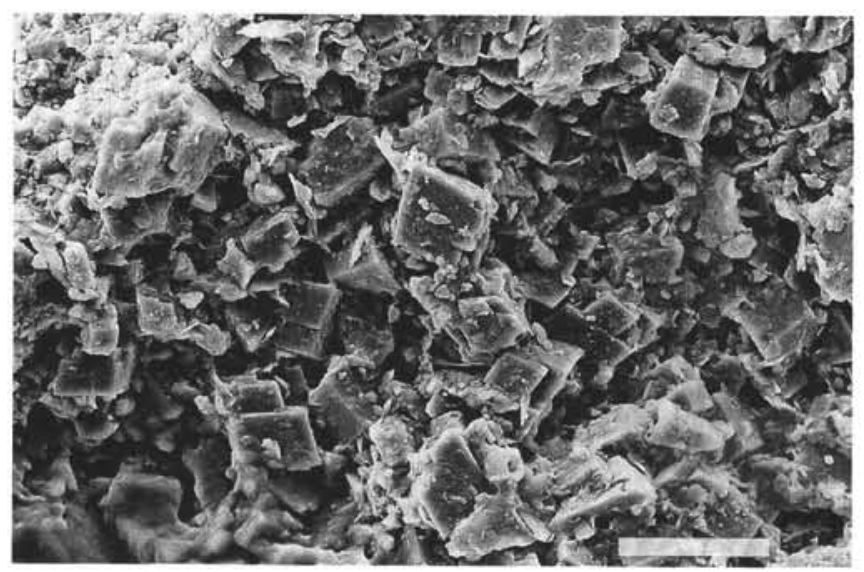

3

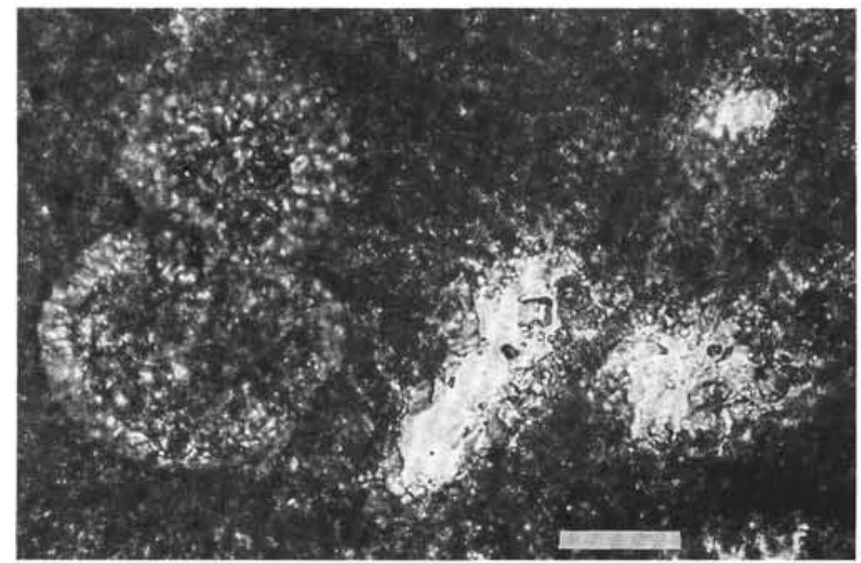

2

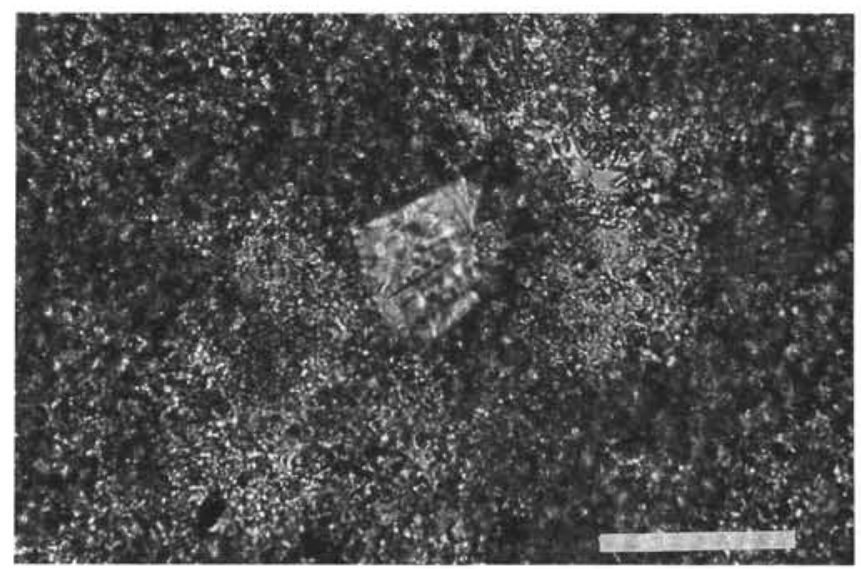

4

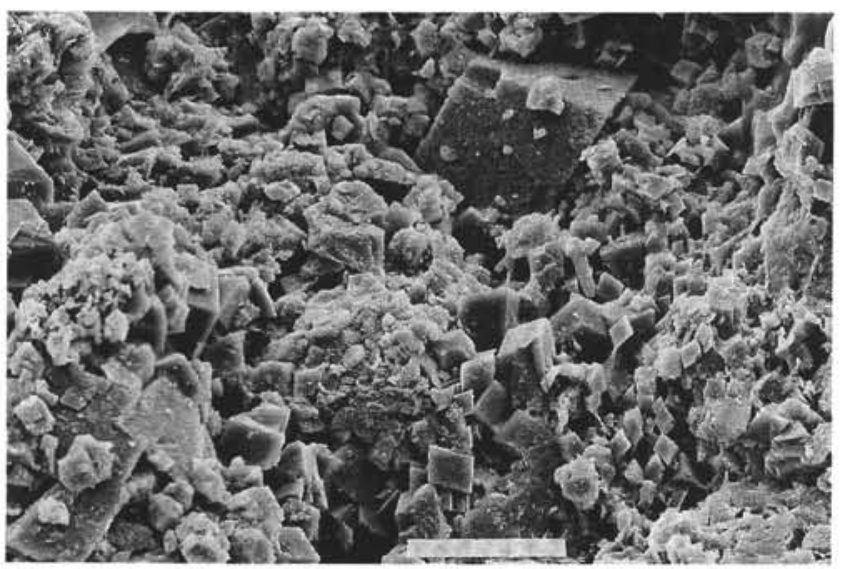

5

Plate 1. 1. Section of lithified carbonate layer (Core 124-768B-25X-CC, $0-7 \mathrm{~cm}$ ). White dots are foraminifers, bioturbation is represented by Chondrites and Zoophycos. Scale bar: $1 \mathrm{~cm}$. 2. Thin section photograph of Sample 124-768B-23H-1, 2-6 cm, with pore-fill dolomite and planktonic foraminifers. Scale bar: 0.5 $\mathrm{mm}$. 3. SEM photograph of the same sample as in 2. Dolomite crystals have grown on the wall of a void (burrow). Note microsparite of the matrix at the upper left. Scale bar: $20 \mu \mathrm{m}$. 4. Dolomite rhomboeder, Sample 124-768B-25X-CC (49-51 cm). Scale bar: $0.5 \mathrm{~mm}$. 5. SEM photograph of the same sample with large dolomite rhomboeder (approx. $25 \mu \mathrm{m}$ in size) in a matrix of smaller crystals (5-10 $\mu \mathrm{m}$ in size). Scale bar: $20 \mu \mathrm{m}$. 